\title{
Environmental Uncertainty and Manager's Personnel Value Affect on Environmental Disclosure
}

\author{
Luk Luk Fuadah ${ }^{*}$, Yulia Saftiana, Umi Kalsum \\ Department of Accounting, Faculty of Economics, Universitas Sriwijaya, Indonesia \\ *corresponding author e-mail : lukluk_fuadah@ unsri.ac.id
}

\begin{tabular}{l}
\hline Article Info \\
\hline Keywords: \\
Environmental uncertainty; \\
Manager personnel value; \\
Environmental disclosure
\end{tabular}

JEL Classification:

M12, M41, Q56

DOI:

10.33830/jom.v17i2.1402.2021

\section{Article History}

Received: March 19, 2021

Accepted: July 27, 2021

Published: November 15, 2021

\begin{abstract}
This study aims to examine the effect of environmental uncertainty and managers' personnel value on environmental disclosure. This study uses a saturated sampling of manufacturing companies listed on the Indonesia Stock Exchange, and the respondents are all managers' levels. The total sample of this study is 161 manufacturing companies. The respondents got the questionnaires via email, and 64 respondents completed them. These can be processed using the Structural Equation Model - Partial Least Square. Findings. The result shows that environmental uncertainty and managers' personnel value have a positive effect on environmental disclosure. Furthermore, this result shows that the manager's personnel value is the most dominant influence of environmental disclosure. These research findings add to the literature, especially about environmental disclosure, and support contingency theory and structuration theory. The findings can give information especially environmental disclosure for the manufacturing companies in Indonesia Stock Exchange. The policymaker should concern about environmental disclosure for companies listed on Indonesia Stock Exchange. The limitation of this research is the low response from the respondents of the research. Another limitation is related to R-Square's results, which still need further research.
\end{abstract}

\section{Introduction}

Environmental disclosure is part of reporting on corporate social responsibility. The report on social responsibility provides information about human resources, community involvement, energy, and the environment. Deegan and Gordon, (1996) reveal that the disclosure of social responsibility is related to the organization's social and physical environment. They interviewed several environmental organizations in Australia. They also selected some industries that received the most attention from the group and measured their environmental sensitivity. They found that firms in sectors with higher environmental sensitivity would see managers increase their level of environmental disclosure under pressure from environmental organizations.

Nguyen et al. (2019) used a sample of 170 issuers listed on the Hanoi Stock Exchange regarding the environmental information disclosure, which is still low. Three sectors have a high level of environmental concern, namely utilities, oil, and gas (water, gas, electricity production, and distribution), construction materials (production of bricks, cement, and concrete, etc.), and 
essential resources (metal, mining, paper). The published information about the environment is environmental obligations, violations regarding the environment, and environmental policies and objectives (Nguyen et al., 2019).

Environmental uncertainty effects on environmental disclosure using the contingency theory. The fundamental essence of contingency theory also states that people must adapt to their contingent structure, namely the environment, organization's size, and business strategy, to run well (Gerdin and Greve, 2004). They conducted a meta-analysis of various studies and found that contextual factors are very influential in designing a management control system (Chenhall, 2003, 2007). These factors are environment, technology, organizational structure, organizational size, strategy, and organizational culture. One of them is an uncertainty environment. Pondeville, Swaen, \& De Ronge, (2013) research the manufacturing companies in Belgian. The results of their survey showed that companies with high ecological, environmental uncertainty would result in the underdevelopment of a proactive environmental strategy, environmental information system, or formal environmental management control system (Pondeville et al., 2013).

Environmental uncertainty poses challenges for all companies today due to the lack of information on green accounting and the speed of information on the environment as limiting factors in taking action. Conditions of high uncertainty, sophisticated information can assist managers in improving the quality of decisions and reduce environmental impact because this information provides several alternatives and solutions. Thus this can be useful for accountability and transparency in making environmental management decisions (Cadman et al., 2016). Environmental uncertainty is an unpredicTable situation, for example, natural disasters or climate change or the rate of market change, for instance, competitor challenges, technological changes, and customer desires that can result in companies being better able to adapt well in the present and the future (Pondeville et al., 2013). On the other hand, these changes can cause new uncertainties related to the uncertainty of the perceived ecological environment or the natural environment (Lewis \& Harvey, 2001).

Environmental uncertainty is a contingency concept related to the environment by considering environmental uncertainty with environmental characteristics and its adaptation (Darvishmotevali et al., 2020). Environmental uncertainty is one of the contingent factors managed by the company. The factor of environmental uncertainty is one of the factors of the organization by adjusting the organizational conditions to the environment (Dwirandra \& Astika, 2020). AbuRahma \& Jaleel (2019) revealed that environmental uncertainty affects business in an organization, affecting environmental information in decision-making. Furthermore, Lin \& Ho (2011) used 322 samples from the Chinese logistics industry. They concluded that environmental uncertainty has a negative and significant impact on green practice adoption (Lin \& Ho, 2011). Research conducted in Singapore. They showed that environmental uncertainty affected environmental scanning (Zhang et al., 2012). They conclude that effective environmental scanning requires organizing and gathering information and clearly defining the need for appropriate information processing, monitoring, dissemination, and evaluation (Zhang et al., 2012). Pondeville et al. (2013) used the sample from Belgian manufacturing companies. They concluded that the environmental uncertainty shows insignificant results with the environmental information system (Pondeville et al., 2013). On the other hand, environmental uncertainty positively impacts waste, energy, and resource management from Malaysian manufacturing firms (Ali et al., 2019).

Cormier, Gordon, and Magnan, (2004) researched in European and North American multinational companies showing that environmental managers' attitudes towards various stakeholder groups and how these managers respond to stakeholders through decisions in 
disclosing and disclosing the real ones, especially regarding environmental disclosures. Fukukawa, Shafer, and Lee, (2007) argued that attitudes towards the environment test values and attitudes towards socio-environmental accountability support. They conducted a study in which MBA students were respondents at a private university in the United States (Fukukawa et al., 2007). Schultz et al., (2005) revealed the environmental values and attitudes of six countries, namely Germany, Brazil, the Czech Republic, New Zealand, India, and Russia. In addition, Roxas \& Coetzer (2012) examined 166 small manufacturing companies located in three Philippine cities. This study investigates the positive attitudes of company owner-managers that influence the company's overall attitude towards environmental sustainability. Borghesi, Houston, and Naranjo, (2014) conclude that CEO personnel characteristics have a positive and significant impact on the investment of Corporate Social Responsible. The research results from Clarkson, Fang, Li, and Richardson (2013) showed that top management has a proactive environmental strategy to disclose about the environment that is transparent and beneficial voluntarily.

The previous discussion has described that managerial personnel values that affect environmental disclosure should be analyzed in organizational structure because the structure is very important in understanding the agency's potential (Sewell, 1992). Sewell (1992) explains that although all agents have an agency in principle, the institution's capacity to open up is facilitated by different structures that empower agents in different ways. As a result, the same agency will never be ascribed to all agents (in all contexts). It is a structure that empowers agents to make themselves visible in various organizational contexts (commitments, practices, routines, and habits). Only with the support of this structure can agents see their intentions, desires, and values (Orlikowski, 2000; Sewell, 1992; Whittington, 2015).

Manager's personnel values affect environmental disclosure based on structuration theory. This structuration theory reveals that structures are rules and resources organized as characteristics of social systems. Thus, structures exist only as 'structural properties'. Meanwhile, the system is a reproducible relationship between actors or collectivities, organized regularly by social practices. However, the concept of structuration is a provision that governs the continuity or transformation of structures, and therefore the reproduction of the system (Giddens, 1979). Structural theory illustrates a framework for investigating the internal and external structures of using management accounting information (Pierce, 2016), the manager's experience, and other networks of managers (Coad et al., 2018). The theory of structuration uses accounting and management disciplines (Makrygiannikis \& Lisa Jack, 2018), management (Kholeif \& Jack, 2019), and social sciences (Morse, 2020).

Bellamy et al. (2020) described that environmental disclosure illustrates information about the impacts and practices regarding the company's environment. Kim et al. (2020) stated that this environmental disclosure is still voluntary. Fan et al., (2020) stated that environmental disclosure provides economic benefits. However, according to Bellamy et al. (2020), environmental disclosure affects company value, reputation, and performance. Boura et al. (2020) stated environmental disclosure is non-financial information to benefit reputation. Shahab et al. (2018) revealed that environmental disclosure provides information to external parties regarding activities, environmental policies, and company performance.

Furthermore, firms cannot make accurate trade-offs between informed environmental decisions from a cost and benefits standpoint. Executives have the flexibility to make decisions. Many decision-making problems are similar, such as green innovation decisions in companies, so that further research can lead to research into other situations (Ma et al., 2019). Based on the previous study showed the different results of why this research is conducted. 
Thus, this study is essential to research factors that influence environmental disclosure in manufacturing companies listed on Indonesia Stock Exchange. Environmental uncertainty and manager's personnel value effect on environmental disclosure is essential to investigate in Indonesia due to the lack of empirical evidence about these variables. The result can give suggestions and also information about environmental disclosure for manufacturing companies especially. The implication is to investigate the environmental uncertainty and manager's personnel value in the role of environmental disclosure. Another implication is the findings give a different result.

This study investigates the effect of environmental uncertainty on environmental disclosure and managers' personnel value on environmental disclosure in manufacturing companies listed on the Indonesia Stock Exchange. This research aims to analyze the influence of environmental uncertainty and managers' personnel values on environmental disclosure. Thus the hypotheses are as follow:

$\mathbf{H}_{1}$ : environmental uncertainty has a positive impact on environmental disclosure.

$\mathbf{H}_{2}$ : manager's personnel value has a positive impact on environmental disclosure.

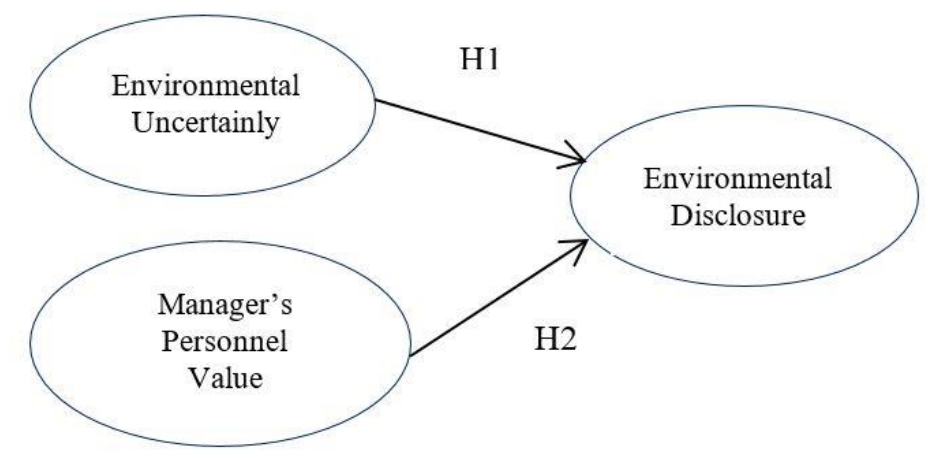

Figure 1. Research Model

\section{Research Method}

This study uses quantitative research. The quantitative research uses primary data from the respondents who answered the online survey questionnaires. The variables in this study are environmental uncertainty, manager's personnel value, and environmental disclosure in manufacturing companies on the Indonesia Stock Exchange.

Saturated sampling, the sample in this study is managers from manufacturing companies listed on the Indonesia stock exchange. The respondents of this study are all managers, including financing, human resources managers, production managers, general managers, and others. This study used saturated samples. That is, all populations were as samples in this study. The total population is 161 manufacturing companies, and all as a sample in this study.

Environmental uncertainty is the ability of management to accurately understand external environmental conditions (Dwyer \& Welsh, 1985). Previous studies used the varying strengths of the external environment as an index to measure environmental uncertainty (Liao, Chuang, and To, 2011). However, environmental uncertainty instruments by environmentalists Liao et al. (2011) are more suiTable and thus adapted. These instruments use environmental uncertainty using a 7 Likert scale (1: strongly disagree, 7: strongly agree).

Personnel Manager values are "concepts and beliefs; regarding the last desired state or behavior; those that go beyond a particular situation; guide the selection or evaluation of behavior or events; and are ordered by relative importance"(Hemingway and Maclagan, 2004). This 
variable has also been used to explain environmental responses (Papagiannakis and Lioukas, 2012) and environmental strategies (Fernández, Junquera, and Ordiz, 2006). We used the original questionnaire developed by Schwartz, (2003), to measure the value of self-transcendence to measure the personal value of managers. We used the original questionnaire developed by (Schwartz, 2003), to measure the value of self-transcendence using a Questionnaire with a Likert scale (from 1: strongly disagree until 7: strongly agree).

Environmental disclosures are included in environmental and social responsibility reports or similar disclosures provided at the company (Clarkson et al., 2008). The environmental disclosure developed by Clarkson et al. (2008) is applied to measure companies' quality of environmental information. These instruments are related to environmental disclosure using a 7 Likert scale, a scale of 1 "very not applied" to a scale of 7 "Highly applied". These questionnaires can be seen in Appendix 1. Before the research questionnaires send to respondents, this study has already done the pilot study to look at the reliability and validity of the research questionnaires. This study uses a structural equation model (SEM) using a Partial Least Square (PLS) analysis tool. The Partial Least square is suiTable for valid confirmatory factor analysis and is more reliable (Afthanorhan, 2013). This study has collected data by sending questionnaires via email and also online questionnaires to respondents. Respondents are all managers in manufacturing companies on the Indonesia Stock Exchange.

\section{Results and Discussions}

The variables used in this study are environmental uncertainty, manager's personnel value, and environmental disclosure. Table 1 shows the descriptive statistic from the variables. The minimum value is 1 and the maximum value is 7 , the highest mean value is 5.88 , and the highest standard deviation is 1.33 .

Table 1. Descriptive Statistic

\begin{tabular}{lccccc}
\hline \multicolumn{1}{c}{ Variable } & N & Min & Max & Mean & $\begin{array}{c}\text { Std } \\
\text { Deviation }\end{array}$ \\
\hline Environmental Uncertainty & 64 & 1 & 7 & 5.63 & 1.15 \\
Manager's Personnel Value & 64 & 2 & 7 & 5.88 & 1.05 \\
Environmental Disclosure & 64 & 1 & 7 & 5.53 & 1.33 \\
\hline
\end{tabular}

Source: Data processed, 2021

This study distributes online questionnaires to approximately 161 manufacturing companies listed on the Indonesia Stock Exchange. The returned questionnaires were 73 questionnaires, but there were 9 incomplete questionnaires, so that the data that could be processed was about 64 . The following Table reveals the percentage of returned questionnaires.

Table 2. Questionnaires rate of return

\begin{tabular}{lcc}
\hline \multicolumn{1}{c}{ Criteria } & Total & Percentage \\
\hline Distributed questionnaires & 161 & 100 \\
Returned & 73 & 45 \\
Incomplete questionnaires & 9 & 6 \\
The Process Data & 64 & 40 \\
\hline
\end{tabular}

Source: Data processed, 2021 
Table 3. Data of Respondents

\begin{tabular}{llcc}
\hline & Description & Total & Percentage (\%) \\
\hline \multirow{2}{*}{ Gender } & Male & 43 & 67,2 \\
& Female & 21 & 32,8 \\
Age & $30-40$ years & 53 & 82,8 \\
& $41-50$ years & 10 & 15,6 \\
Education Level & $>51$ & 1 & 1,6 \\
& Bachelor & 53 & 82,8 \\
& Master & 11 & 17,2 \\
& Financial & 20 & 31,25 \\
Division & Human Resources & 7 & 10,94 \\
& General & 5 & 7,81 \\
& Marketing & 3 & 4,69 \\
& Production & 12 & 18,75 \\
& Environmental & 9 & 14,06 \\
\hline
\end{tabular}

Source: Data processed, 2021

The data based on gender shows as many as 43 men (67.2\%) and the rest $32.8 \%$ women. Based on the age of the respondents, there were 53 people aged between 30 to 40 years or $82.8 \%$. The rest is between $15.6 \%$ for 41 to 50 years old, and the rest is $1.6 \%$. For the education, most of them were at the undergraduate level as much as $82.8 \%$, and the rest were at the master's level as much as $17.2 \%$. Finally, the most workplace division is in the finance division with 20 people $(31.25 \%)$. The rest varies from the production division, environment division, resource division, general division, marketing division, and other divisions.

\subsection{Analyze the Outer Model}

Model Partial least square analysis uses the goodness of fit model from the average RSquared (ARS) to show the model's suitability. It can be seen Table from Table 4. The average path coefficient (APC) to reveal the interrelations between variables, and the average variance inflation factor (AVIF) indicate the multicollinearity among independent variables (Hapsoro \& Falih, 2020).

Table 4. The goodness fit of Model

\begin{tabular}{cccc}
\hline Result & P-value & Criteria & Description \\
\hline APC $=0,368$ & $\mathrm{P}<0,001$ & Good if $\mathrm{P}<0,001$ & Supported \\
ARS $=0,408$ & $\mathrm{P}<0,001$ & Good if $\mathrm{P}<0,001$ & Supported \\
$\mathrm{AVIF}=1,236$ & & $\mathrm{P}<5$ & Supported \\
\hline Source: Data processed, 2021 & &
\end{tabular}

\subsection{Analyze the inner model}

Based on Table 5, it can be seen that the loading factor value for each indicator is $>0.5$, the AVE value is $>0.5$, and the composite reliability value is $>0.7$. Thus, all constructs and research indicators have met the criteria. 
Table 5. Loading factor values, AVE, and composite reliability

\begin{tabular}{ccccc}
\hline Variable & Indicator & $\begin{array}{c}\text { Outer Loading } \\
\text { Factor Value }\end{array}$ & AVE & $\begin{array}{c}\text { Composite } \\
\text { Reliability }\end{array}$ \\
\hline Uncertainty Environment & KPL1 & 0.749 & 0.531 & 0.748 \\
& KPL2 & 0.757 & & \\
& KPL3 & 0.549 & & \\
& KPL4 & 0.587 & & \\
& KPL5 & 0.512 & 0.575 & \\
Manager Personnel Value & NPM1 & 0.788 & & \\
& NPM2 & 0.896 & & \\
& NPM3 & 0.729 & & \\
& NPM4 & 0.802 & & \\
Environmental Disclosure & NPM5 & 0.710 & & \\
& PL1 & 0.585 & 0.579 & \\
& PL2 & 0.835 & & \\
& PL3 & 0.910 & & \\
& PL4 & 0.739 & & \\
& PL5 & 0.641 & & \\
& PL6 & 0.883 & & \\
& PL7 & 0.919 & & \\
\hline
\end{tabular}

Source: Data processed, 2021

Table 6. The Results of Cronbach Alpha, Composite Reliability, and Average Variance Extracted

\begin{tabular}{cccccc}
\hline & Cut Off Value & KPL & NPM & PL & Note \\
\hline Cronbach Alpha & $>0,6$ & 0,583 & 0,821 & 0,872 & \\
Composite Reliability & $>0.7$ & 0,748 & 0,875 & 0,904 & All item meet the \\
Average Variance & $>0,5$ & 0,559 & 0,584 & 0,579 & requirement \\
Extracted & & & & & \\
\hline
\end{tabular}

Source: Data processed, 2021

Note: $\mathrm{KPL}=$ Environmental uncertainty, NPM = Manager's Personnel Value, PL = Environmental disclosure.

The $\mathrm{R}$ Square is about 0.408 , meaning that environmental uncertainty and manager's personnel value could explain the environmental disclosure variable by $40.8 \%$. We used three steps in analyzing with Partial Least Square (PLS). The first step is related to the outer model includes composite reliability, Cronbach's Alpha, and Average Variance extracted. The second step, the reliability of constructs, for the composite reliability value above 0,7 , for the Cronbach's Alpha above 0,60. The last step, the Average Variance Extracted (AVE) is about 0,4 (Ghozali, 2013). From Table 4 shows that all the outer model can fulfill and has good validity. Based on Chin (1998) if the value of $R$ Square $\left(R^{2}\right)$ is 0,19 , it is a weak level. If the value of $R$ Square $\left(R^{2}\right)$ is 0,33 , it is moderate. If the value of $R$ Square $\left(R^{2}\right)$ is 0,67 , it is strong.

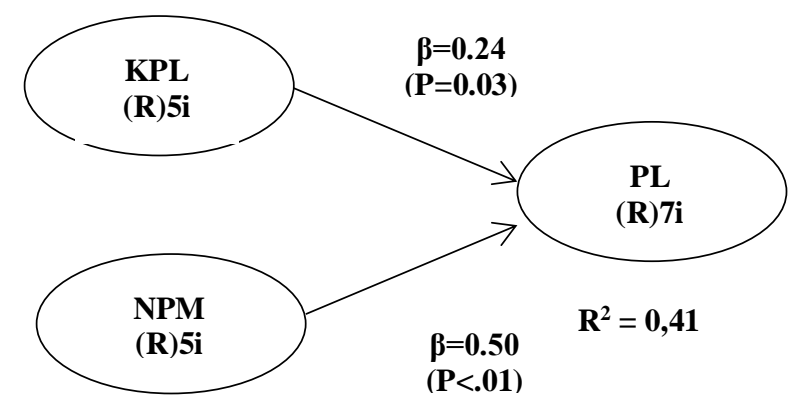

Figure 2. The result of Research from PLS 
Based on Figure 2 and Table 7 shows that the result of the research. All the hypotheses are accepted or supported. The value of the path coefficient $(\beta)$ on the effect of KPL $\rightarrow$ PL is 0.24 , the p-value is 0.03 . This means that hypothesis 1 (H1) is fully supported. Environmental uncertainty has a positive and significant effect on environmental disclosure that supports previous research (Zhang et al., 2012).

Table 7. The result of hypotheses

\begin{tabular}{llll}
\hline Hypothesis & $\boldsymbol{\beta}$ & P-value & Result \\
\hline $\mathrm{KPL} \rightarrow \mathrm{PL}\left(\mathrm{H}_{1}\right)$ & 0,24 & 0,03 & Supported \\
$\mathrm{NPM} \rightarrow \mathrm{PL}\left(\mathrm{H}_{2}\right)$ & 0,50 & $<0,01$ & Supported \\
\hline
\end{tabular}

Source: Data processed, 2021

The final hypothesis is NPM $\rightarrow$ PL $\left(\mathrm{H}_{1}\right)$ which reveals the effect of manager personnel value which has a positive and significant effect on environmental disclosure. The path coefficient $(\beta)$ is 0.50 with a p-value $<0.01$. This means that hypothesis $2\left(\mathrm{H}_{2}\right)$ shows that the hypothesis is accepted. Thus, the result of this study supports the previous research (Borghesi et al., 2014; Clarkson et al., 2013; Cormier et al., 2004).

The first hypothesis $\left(\mathrm{H}_{1}\right)$ states that environmental uncertainty affects environmental disclosure, which is empirically accepted. This means that Hypothesis 1 is supported. The higher the environmental uncertainty, the greater the environmental disclosure made by companies. Research supports previous research related to environmental uncertainty and environmental disclosure (Zhang et al., 2012). Environmental uncertainty is an unpredicTable situation, including natural disasters, climate change, to respond now and in the future (Pondeville et al., 2013). Environmental uncertainty is a challenge for every company today and is linked to the lack of environmental information and the speed of environmental information as limiting factors for action. In conditions of high uncertainty, fast information can help managers improve decision quality and reduce environmental impact because this information provides several alternatives and solutions in decision making (Cadman et al., 2016). Thus, environmental uncertainty requires information about the environment. This research also supports the contingency theory. The underlying theory is a contingency theory, namely the influence of environmental uncertainty and environmental disclosure (Otley, 1980). Thus, it can be concluded that the environmental uncertainty affects on the decision making, one of them is to disclose environment for company based on the contingency theory.

The last hypothesis $\left(\mathrm{H}_{2}\right)$ states that "Manager's Personnel Value positively affects environmental disclosure". Empirical evidence from the results of this study can be concluded that H2 is supported. This finding support Luque-Vílchez et al. (2019) revealed that manager personnel values positively affect environmental disclosure a result from Spanish firms. Papagiannakis and Lioukas (2012) showed managers' personnel values influence environmental disclosure. Whittington, (2015) describes the transformation of manager personnel values into actual changes in social interactions. The determinant role of the structure is what makes Giddens (1984) refer to the mediating role of structure in actor agents: structure always underlines agency in social action (Giddens, 1984). In this case, the effect of structure mediation on actor agency can represent a structural or empowerment constraint. That is, the structure can determine the direction and intensity of agency effects (Archer, 2003; Giddens, 1984). This finding result supports the Structuration theory. 


\section{Conclusions}

The result of the research shows that all hypotheses are supported. Environmental uncertainty has a positive and significant impact on environmental disclosure. It means that the higher the uncertainty environment, the higher the environmental disclosure. The manager's personnel values also have a positive and significant impact on environmental disclosure. The higher manager's personnel values, the higher the environmental disclosure.

There are several limitations of this study. The first limitation of this research is the low response from the research object. Another limitation is related to the results of R Square, which still needs to be done further research. Suggestions for future research are to conduct qualitative research, namely conducting case studies and interviews. In addition, the future studies may consider variables that have not been studied, for example, organizational culture, government responsibility, media, and so on.

\section{Acknowledgment}

This research is supported by the Faculty of Economics (Nomor. SP DIPA-023.17.2.677515/2020)

\section{References}

Abu-Rahma, A., \& Jaleel, B. (2019). Perceived uncertainty and use of environmental information in decision making: The case of the United Arab Emirates. International Journal of Organizational Analysis, 27(3), 690-711. https://doi.org/10.1108/IJOA-07-2017-1205

Afthanorhan, W. M. A. B. W. (2013). A comparison of partial least square structural equation modeling (PLS-SEM) and covariance based structural equation modeling (CB-SEM) for confirmatory factor analysis. International Journal of Engineering Science and Innovative Technology, February, 198-205.

Ali, M. H., Zailani, S., Iranmanesh, M., \& Foroughi, B. (2019). Impacts of environmental factors on waste, energy, and resource management and sustainable performance. Sustainability, 11, $1-16$.

Archer, M. S. (2003). Structure, Agency and the Internal Conversation (Issue June). Cambridge University Press.

Bellamy, M. A., Dhanorkar, S., \& Subramanian, R. (2020). Administrative environmental innovations, supply network structure, and environmental disclosure. Journal of Operations Management, 66(7-8), 895-932. https://doi.org/10.1002/joom.1114

Borghesi, R., Houston, J. F., \& Naranjo, A. (2014). Corporate socially responsible investments : CEO altruism, reputation, and shareholder interests. Journal of Corporate Finance, 26, 164181. https://doi.org/10.1016/j.jcorpfin.2014.03.008

Boura, M., Tsouknidis, D. A., \& Lioukas, S. (2020). The role of pro-social orientation and national context in corporate environmental disclosure. European Management Review, 1-14. https://doi.org/10.1111/emre.12416

Cadman, T., Maraseni, T. N., Breakey, H., Lopez-casero, F., \& Bay, H. (2016). Governance values in the climate change regime : Stakeholder perceptions of REDD + legitimacy at the national level governance values in the climate change regime: Stakeholder perceptions of REDD + legitimacy at the national level. Forest, 7(September), 1-17. https://doi.org/10.3390/f7100212

Chenhall, R. H. (2003). Management control systems design within its organizational context: findings from contingency based research and directions for the future. Accounting, Organizations \& Society, 28, 127-168. https://doi.org/10.1063/1.5024417

Chenhall, R. H. (2007). Multiple perspectives of performance measures. European Management 
Journal, 25(4), 266-282. https://doi.org/10.1016/j.emj.2007.06.001

Clarkson, P. M., Fang, X., Li, Y., \& Richardson, G. (2013). The relevance of environmental disclosures: Are such disclosures incrementally informative? Journal of Accounting and Public Policy, 32(5), 410-431. https://doi.org/10.1016/j.jaccpubpol.2013.06.008

Clarkson, P. M., Li, Y., Richardson, G. D., \& Vasvari, F. P. (2008). Revisiting the relation between environmental performance and environmental disclosure: An empirical analysis. Accounting, Organizations and Society, 33(4-5), 303-327. https://doi.org/10.1016/j.aos.2007.05.003

Coad, A., Jack, L., \& Kholeif, A. (2018). Strong structuration theory in accounting research. Meditari Accountancy Research, 1-7.

Cormier, D., Gordon, I. M., \& Magnan, M. (2004). Corporate environmental disclosure: Contrasting management's perceptions with reality. Journal of Business Ethics, 49, 143-165.

Darvishmotevali, M., Altinay, L., \& Köseoglu, M. A. (2020). The link between environmental uncertainty, organizational agility, and organizational creativity in the hotel industry. International Journal of Hospitality Management, 87(January), 102499. https://doi.org/10.1016/j.ijhm.2020.102499

Deegan, C., \& Gordon, B. (1996). A study of the environmental disclosure practices of Australian corporations. Accounting and Business Research, 26(3), 187-199. https://doi.org/10.1080/00014788.1996.9729510

Dwirandra, A. A. N. B., \& Astika, I. B. P. (2020). Impact of environmental uncertainty, trust and information technology on user behavior of accounting information systems. The Journal of Asian Finance, Economics and Business, 7(12), 1215-1224. https://doi.org/10.13106/jafeb.2020.vol7.no12.1215

Dwyer, F. R., \& Welsh, M. A. (1985). Environmental relationship of the internal political economy of marketing channels. Journal of Marketing Research, 22(4), 397-414.

Fan, L., Yang, K., \& Liu, L. (2020). New media environment, environmental information disclosure and firm valuation: Evidence from high-polluting enterprises in China. Journal of Cleaner Production, 277, 1-8. https://doi.org/10.1016/j.jclepro.2020.123253

Fernández, E., Junquera, B., \& Ordiz, M. (2006). Managers' profile in environmental strategy : A review of the literature. Corporate Social Responsibility and Environmental Management, 13, 261-274.

Fukukawa, K., Shafer, W. E., \& Lee, G. M. (2007). Values and attitudes toward social and environmental accountability: A study of MBA students Kyoko Fukukawa. Journal of Business Ethics, 71(January), 381-394. https://doi.org/10.1007/s10551-005-3893-y

Gerdin, J., \& Greve, J. (2004). Forms of contingency fit in management accounting research - a critical review. 29, 303-326. https://doi.org/10.1016/S0361-3682(02)00096-X

Ghozali, I. (2013). Partial Least Square. In Universitas Diponegoro. Elsevier B.V.

Giddens, A. (1979). Central Problems in Social Theory Action, Structure and Contradiction in Social Analysis. Macmillan Education Ltd.

Giddens, A. (1984). The Constitution of Society (Cambridge (ed.)). Polity Press.

Hapsoro, D., \& Falih, Z. N. (2020). The effect of firm size, profitability, and liquidity on the firm value moderated by carbon emission disclosure. Journal of Accounting and Investment, 21(2), 240-257. https://doi.org/10.18196/jai.2102147

Hemingway, C. A., \& Maclagan, P. W. (2004). Managers' personal values as drivers of corporate social responsibility. Journal Business Ethics, 50(1), 33-44.

Kholeif, A. O. R., \& Jack, L. (2019). The paradox of embedded agency from a strong structuration perspective: An illustrative case study of resistance to change in budgeting processes. Qualitative Research in Accounting and Management, 16(1), 60-92. https://doi.org/10.1108/QRAM-03-2016-0027

Kim, I., Ryou, J. W., \& Yang, R. (2020). The color of shareholders' money: Institutional 
shareholders' political values and corporate environmental disclosure. Journal of Corporate Finance, 64(July), 1-23. https://doi.org/10.1016/j.jcorpfin.2020.101704

Lewis, G. J., \& Harvey, B. (2001). Perceived environmental uncertainty: The extension of miller's scale to the natural environment. Journal of Management Studies, 38(2), 201-233.

Liao, C., Chuang, S., \& To, P. (2011). How knowledge management mediates the relationship between environment and organizational structure. Journal of Business Research, 64(7), 728736. https://doi.org/10.1016/j.jbusres.2010.08.001

Lin, C., \& Ho, Y. H. (2011). Determinants of green practice adoption for logistics companies in China. Journal of Business Ethics, 98, 67-83. https://doi.org/10.1007/s10551-010-0535-9

Luque-Vílchez, M., Mesa-Pérez, E., Husillos, J., \& Larrinaga, C. (2019). The influence of proenvironmental managers' personal values on environmental disclosure: The mediating role of the environmental organizational structure. Sustainability Accounting, Management and Policy Journal, 10(1), 41-61. https://doi.org/10.1108/SAMPJ-01-2018-0016

Ma, Y., Zhang, Q., Yin, Q., \& Wang, B. (2019). The influence of top managers on environmental information disclosure: The moderating effect of company's environmental performance. International Journal of Environmental Research and Public Health, 16, 1-15. https://doi.org/10.3390/ijerph16071167

Makrygiannikis, G., \& Lisa Jack. (2018). Designing a conceptual methodology for structuration research Georgios. Meditari Accountancy Research, 26(1), 1-26.

Morse, W. C. (2020). Recreation as a social-ecological complex adaptive system. Sustainability, 12(3), 1-16. https://doi.org/10.3390/su12030753

Nguyen, T. K. T., Nguyen, N. T., \& Nguyen, T. M. H. (2019). Assessing the level of environmental information disclosure by listed companies on the stock market in Vietnam. Problems and Perspectives in Management, 17(3), 207-217. https://doi.org/10.21511/ppm.17(3).2019.17

Orlikowski, W. J. (2000). Using technology and constituting structures: A practice lens for studying technology in organizations. Organization Science, 11(4), 404-428.

Otley, D. T. (1980). The contingency theory of management accounting: Achievement and prognosis. Accounting, Organizations and Society, 5(4), 413-428. https://doi.org/10.1016/0361-3682(80)90040-9

Papagiannakis, G., \& Lioukas, S. (2012). Values, attitudes and perceptions of managers as predictors of corporate environmental responsiveness. Journal of Environmental Management, 100, 41-51. https://doi.org/10.1016/j.jenvman.2012.01.023

Pierce, O. F. B. (2016). Strong structuration theory \& accounting information: An empirical study. Accounting, Auditing \& Accountability Journal, 29(7), 1-43.

Pondeville, S., Swaen, V., \& De Rongé, Y. (2013). Environmental management control systems: The role of contextual and strategic factors. Management Accounting Research, 24(4), 317332. https://doi.org/10.1016/j.mar.2013.06.007

Roxas, B., \& Coetzer, A. (2012). Institutional environment, managerial attitudes and environmental sustainability orientation of small firms. Journal Business Ethics, 111, 461476. https://doi.org/10.1007/s10551-012-1211-z

Schultz, P. W., Gouveia, Valdiney, V., Cameron, L. D., Tankha, G., Schmuck, P., \& Franek, M. (2005). Values and their relationship to environmental concern and conservation behavior. Journal of Cross-Cultural Psychology, 36(July), 457-475. https://doi.org/10.1177/0022022105275962

Schwartz. (2003). A proposal for measuring value orientations across nations", Package of the European Social Survey. Available at: Www.Europeansocialsurvey.Org/Docs/Methodology/ Core_ess_questionnaire/ESS_core_questionnaire_human_values.Pdf.

Sewell, W. H. (1992). A theory of structure: And transformation1 duality, agency. American Journal of Sociology, 98(1), 1-29.

Shahab, Y., Ntim, C. G., Chengang, Y., Ullah, F., \& Fosu, S. (2018). Environmental policy, environmental performance, and financial distress in China: Do top management team 
characteristics matter?. Business Strategy and the Environment, 27(8), 1-18. https://doi.org/10.1002/bse.2229

Whittington, R. (2015). Giddens, structuration theory and strategy as practice (C. Handbook \& of Strategy as Practice (eds.); Issue January). Cambridge Press,. https://doi.org/10.1017/CCO9781139681032.009

Zhang, X., Majid, S., \& Foo, S. (2012). Perceived environmental uncertainty, information literacy and environmental scanning : Towards a refined framework. Information Research, 17(2), 121.

\section{Appendix 1.}

Table 1. Environmental Uncertainty

\begin{tabular}{cl}
\hline No & \multicolumn{1}{c}{ Indicator } \\
\hline 1 & Diversity on the needs of customers \\
2 & Diversity from competition \\
3 & Similarities to Suppliers \\
4 & Size of the Allies (Partnership) \\
5 & The number of competitors \\
\hline
\end{tabular}

Table 2. Manager's Personnel Value

\begin{tabular}{cl}
\hline No & \multicolumn{1}{c}{ Indicator } \\
\hline 1 & $\begin{array}{l}\text { Universalism } \\
\text { Everyone in the world is treated the same. He wanted justice for everyone, even for } \\
\text { people he didn't know }\end{array}$ \\
2 & $\begin{array}{l}\text { It is important to listen to people who are different from him. Even when he } \\
\text { disagreed with them, he still wanted to understand them } \\
3\end{array}$ \\
I believe that humans should care about nature. \\
Virtue \\
5 & $\begin{array}{l}\text { It is very important for me to help those around him. He wants to take care of others } \\
\text { It is important for me to be loyal to his friends. He wants to devote himself to those } \\
\text { who are close to him }\end{array}$ \\
\hline
\end{tabular}

Table 3. Environmental Disclosure

\begin{tabular}{cl}
\hline No & \multicolumn{1}{c}{ Indicators } \\
\hline 1 & Governance structures and management systems related to an environment such as \\
& $\begin{array}{l}\text { ISO 14001 } \\
2\end{array}$ \\
& $\begin{array}{l}\text { Credibility related to the use of the Global Reporting Index, certification and } \\
\text { linkages from Stakeholders. }\end{array}$ \\
3 & $\begin{array}{l}\text { Environmental Performance Indicators related to the efficient use of natural } \\
\text { resources, gas. }\end{array}$ \\
4 & Expenditures related to the environment \\
5 & Vision and Strategy Claims \\
6 & Environmental Profile \\
7 & Environmental initiatives related to training, awards, audits \\
\hline
\end{tabular}

